\title{
Weather-company chief is Trump's pick to lead climate agency
}

Barry Myers would bring private weather-forecasting experience to the National Oceanic and Atmospheric Administration.

Jeff Tollefson

12 October 2017 Updated: 12 October 2017

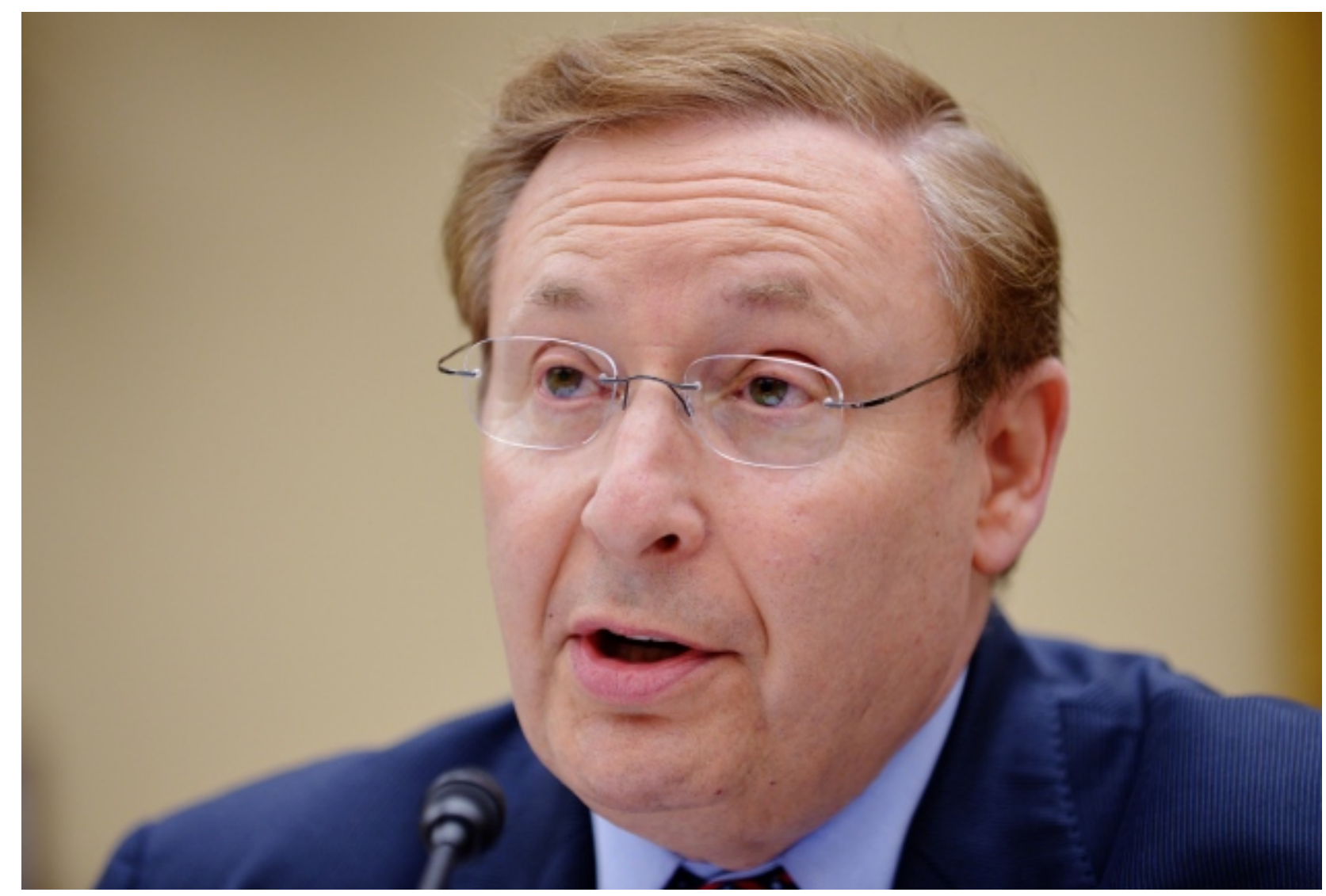

Mandel Ngan/AFP/Getty

Barry Myers has been nominated to lead the US National Oceanic and Atmospheric Administration.

Barry Myers, the chief executive of weather-forecasting firm AccuWeather, is US President Donald Trump's pick to head the National Oceanic and Atmospheric Administration (NOAA), the White House said on 11 October. 
Myers, an attorney by training, has led AccuWeather - based in State College, Pennsylvania - since 2007. This experience could prove useful if the US Senate confirms Myers as NOAA's chief, given that the agency includes the US National Weather Service. But some scientists worry that Myers's ties to AccuWeather could present conflicts of interest, and note that Myers has no direct experience with the agency's broader research portfolio, which includes the climate, oceans and fisheries.

"I think the science community has real cause for concern," says Andrew Rosenberg, head of the Center for Science and Democracy at the Union of Concerned Scientists in Cambridge, Massachusetts.

Rosenberg notes that Myers was an early proponent of carving out a larger role for the private sector in providing weather services. And in 2005, while Myers served as executive vice-president and general counsel, AccuWeather lobbied for legislation to prevent the National Weather Service from competing with private firms in providing products including basic weather forecasting. "Is he going to recuse himself from decisions which might potentially be of interest to his company down the road?" asks Rosenberg.

\section{Related stories}

- US lawmakers' science spending plans ignore Trump cuts

- Trump budget would slash science programmes across government

- Race to provide commercial weather data heats up

More related stories

\section{Related stories}

- US lawmakers' science spending plans ignore Trump cuts

- Trump budget would slash science programmes across government

- Race to provide commercial weather data heats up

More related stories

\section{A different perspective}

Myers will probably advance efforts to bring commercial weather data into the national weatherforecasting system, says Bill Gail, chief technology officer for the Global Weather Corporation in Boulder, Colorado. Still, Gail says, Myers respects the importance of the public sector in such activities. "I've got a lot of respect for him, and I think he could do a pretty good job," adds Gail, the cochair of a decadal survey of US Earth-science satellites being conducted by the National Academies of Sciences, Engineering, and Medicine. 
The chief executive's views on climate change are a little harder to parse, because Myers hasn't taken any strong public positions on global warming. But in a position statement on the Accuweather website, the company says there is "little doubt" that human activities influence the planet's climate. "At the same time, our knowledge of the extent, progress, mechanisms and results of global climate change is still incomplete," the statement says. The company says it encourages its scientists to express their own views, and it publishes a blog featuring posts about climate research.

If Myers ascends to NOAA's top job, he will lead an agency facing an uncertain financial future. Trump has proposed slashing NOAA's budget by $17 \%$ in fiscal year 2018, compared to the 2017 level of US $\$ 5.7$ billion. Although Congress has so far rebuffed Trump's attempts to cut funding for several key science agencies, funding for the 2018 budget year — which began on 1 October — is still up the air. The government is currently running on a stopgap spending bill that will expire on 8 December, prompting another round of budget negotiations.

Ultimately, Myers will need to build a solid team to handle the full NOAA portfolio, says Antonio Busalacchi, president of the University Corporation for Atmospheric Research in Boulder. "He's going to face a lot of challenges, but the bottom line is that Barry does bring a lot of relevant experience to the table."

Whoever ends up leading the agency will have help. On 5 October, the Senate confirmed oceanographer Timothy Gallaudet as assistant secretary of commerce for oceans and atmosphere, the number-two position at NOAA. Gallaudet, a 32-year veteran of the US Navy, has experience ranging from weather and ocean forecasting to developing policies to counter illegal fishing and assessing the national-security implications of global warming, according to the White House.

Nature doi:10.1038/nature.2017.22311

\section{Updates}

Updated: This story has been updated with information about Myers' views on climate change and the recently confirmed assistant secretary of commerce for oceans and atmosphere, Timothy Gallaudet. 